\title{
The Bay of Plenty; a summary of the physical landscape, economy, demographics and issues surrounding primary production
}

\author{
SIMON STOKES \\ Bay of Plenty Regional Council, PO Box 364 Whakatāne, New Zealand \\ simon.stokes@envbop.govt.nz
}

\begin{abstract}
The "Bay of Plenty" was a term coined by Captain Cook when his ship Endeavour rounded East Cape on 29 October 1769 and came upon local populations large and prosperous. It has a uniquely youthful volcanic landscape, interspersed with twelve iconic lakes, and several harbours and estuaries, the eastern boundary being framed by the main axial range of the North Island. With approximately $71 \%$ of the land area afforested or in indigenous habitat, there is not a huge amount of land left for agricultural and horticultural production; this has to compete with changing community demands, urbanisation and infrastructural growth, and a rapidly expanding population. This raises expectations on the primary sectors to manage their businesses in a way which reduces the effects of those sectors on the surrounding environment. With pumice soils dominating, and water quality an issue, the security and future of the region's primary producers is both necessary and problematic.
\end{abstract}

\section{The Physical landscape}

The Bay of Plenty Regional Area is approximately 1.2 million hectares and defined by the watersheds of many major rivers which end in estuaries or harbours along the famous Bay of Plenty coastline. It has long been populated by our indigenous people as many waka landed along the coast, none more famous than the Mataatua waka that landed just inside the Whakatāne River mouth.

The Bay of Plenty's landscape is defined by two key geological features. In the east are the axial ranges of the North Island - the Huiarau and Ikawhenua ranges, with the treasured high point of Maungapōhatu, running through Te Urewera. They trend north to northeast extending into the Waioeka catchment of oversteepened hill country onwards into the incredibly steep Raukūmara ranges which taper away abruptly at the East Cape and Cape Runaway. These ranges have never been tamed, sometimes cleared around the fringes and pockets in their interior but never completely cleared for farming or forestry. The Raukūmaras in particular are relatively unknown, unexplored and inaccessible. Several rivers, including the Mōtū River, wind their way through them.
The ranges are split by various fault lines which have created the drainage catchments of the Whakatāne, Waimana, and Turanga Rivers, and many others. In fact fault lines are a feature of our region due to the active tectonics displayed by the on-going volcanic history due to the meeting of two tectonic plates directly underneath us.

The western boundary is framed by the Mamaku and Kaimai ranges which are distinctive in their own way due to the extensive ignimbrite. This landscape has not escaped change, and a large proportion of the once densely covered ranges have been cleared and logged, with only the most difficult bush remaining in situ.

In between, there is a landscape defined by volcanism with pyroclastic flows cemented in time as ignimbrite overlain by extensive layers of ash and lapilli mantling the hills and re-deposited into the valleys and plains. The last eruption occurred less than 200 hundred years ago when Mount Tarawera erupted and deposited Tarawera ash and Rotomahana mud over a wide area.

In the wake of the all the volcanism, twelve lakes were formed in the Rotorua District and each has become famous and iconic in its own way as a tourist destination and recreational retreat.

Because of the high volumes of material erupted into the landscape and the mobile environment due to a healthy rainfall, valleys and plains have been filled and re-filled many times over. Most of our lower plains were wetland environments which were dynamic and changing, particularly with the sea fluctuating back and forth over the last 30000 years. The plains, remnant wetlands, and estuaries and navigable harbours still remain, but have been managed since settlers began the draining and channelling processes which are on going still today.

The soils are predominantly volcanic in origin. Pumice and Allophanic soil orders dominate across the region, providing a contrast in type and management. Intermingled with these two soil orders are Brown, Organic, Gley, Podzols, Raw and Recent soil orders. The Organic soil order or peat soils are very common in the low lying plains area which was once extensive wetlands of which little remains. Soil fertility is an issue due to the inherent lack of minerals and trace elements.

Nutrient leaching is very relevant to the Bay of 
Plenty because many of the soils have sandy textures, especially the volcanic soils. Nutrients in sandy soils with low organic matter content can be easily leached because the soils are free draining and have low nutrient retention capacities. Our Allophanic and Brown soils have an appreciable clay content and organic matter and do not leach as much because a greater proportion of the inorganic nutrients is adsorbed on the mostly negatively charged exchange complex. But both these soils occur where there is little agriculture and extensive indigenous forest cover. Since texture is a basic soil property that cannot be easily changed, the addition of organic matter to sandy topsoils to increase nutrient holding capacity is very important. In this region, sandy soils with shallow topsoils should be cultivated infrequently and landowners should foster organic matter build up.

\section{Land use, land cover and land use capability}

The region is mostly covered in indigenous vegetation and habitat $(51 \%)$, with a further $24 \%$ in exotic forestry. Grassland (high- and low-producing) is $21 \%$, with orchards and cropland (2.4\%), with the remainder in urban area and lakes (Guinto \& Cusi 2012).

A quarter of the region's (26.3\%) land area is arable (Land Use Capability (LUC) Classes 1-4) while the rest $(73.7 \%)$ belongs to the non-arable categories (LUC Classes 5-8), (Lynn et al. 2009). However the proportion of land that is in primary production is much lower across all LUC Classes (Table 1). LUC Classes 1-4 are used for pastures, short rotation crops, orchards and other perennial crops, and some exotic forestry and indigenous vegetation. Of the non-arable LUC Classes, Classes 6 and 7 have the largest areas $(23.7 \%$ and 33\%, respectively) with most of this landscape in indigenous forest while LUC Class 5 land has the smallest area $(0.06 \%)$. From LUC Class 6 through to LUC Class 8 , the proportion of indigenous forest cover increases sharply (from $28.9 \%$ to $87.9 \%$ ). In general, there appears to be a good match between land use capability and land cover in the region (Table 2). Expanding further, the non-arable LUC classes, notably LUC Class 7 (48.0\%), LUC Class 8 (31.3\%) and LUC Class 6 (16.0\%) lands all contain a large proportion $(>84 \%)$ of the indigenous land cover (Guinto \& Cusi 2012).

The total area of land that is able to be irrigated (LUC classes 1-4) is approximately 167000 hectares or $14 \%$ of the region's total land area (Guinto \& Cusi 2012). There is very limited Class 1 land that is able to be irrigated ( 2834 ha or $1.5 \%$ of the total area), but significantly more areas under LUC classes 2-4 are available, particularly if the afforested land was converted to pasture, cropping or horticulture. How

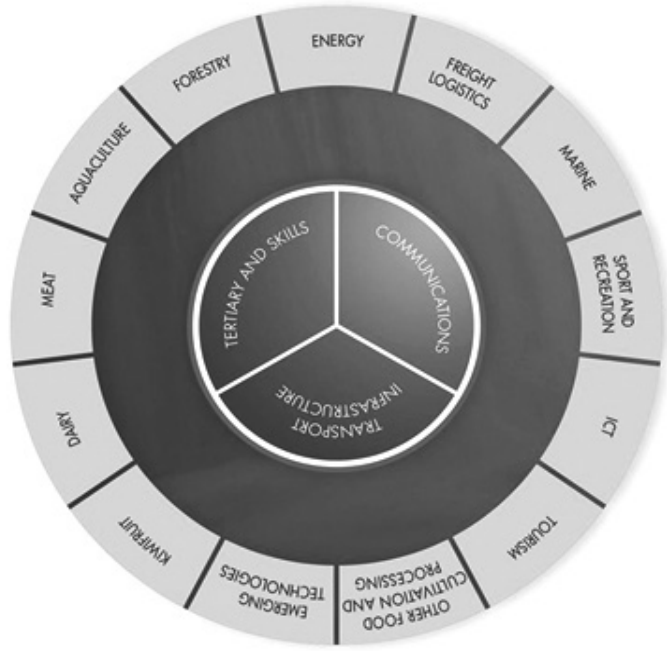

Figure 1 Strategic Focusareas ofindustryfortheBay of Plenty Source: www.bay of connections.com (December 2011)

much land is irrigated currently is unknown. The Bay of Plenty Regional Council has a programme investigating the groundwater resources of the region and has completed the Tauranga and Western Bay of Plenty areas, the lower Rangitāiki Plains and ŌhopeŌpōtiki areas. The Ōpōtiki Plains has substantial water remaining for allocation. A recent report of our 54 monitored groundwater locations showed water levels are currently stable or increasing at 42 sites, with 12 showing a decrease in water level (Bay of Plenty Regional Council 2013a). Those systems in decline tend to be in localised areas and the decline does not extend over the whole aquifer. However, the Tauranga Harbour deep aquifer is showing decline in the north and near the city. Abstraction is exceeding recharge and this is a concern due to the proximity to the coast which could in time lead to saltwater intrusion (Bay of Plenty Regional Council 2013a).

Mean soil erosion rates in tonnes per hectare per year for each land cover type were estimated using the New Zealand Empirical Erosion Model (Guinto \& Cusi 2012). This model was developed for predicting erosion rates under New Zealand conditions. It estimates soil erosion rate as a function of mean annual rainfall, a land cover factor, and an erosion coefficient that depends on the land type that is the erosion terrain. In the Bay of Plenty, landslide or bare ground has the highest mean erosion rate $(6.2 \mathrm{t} / \mathrm{ha} / \mathrm{yr})$ followed by river and lakeshore gravel and rock ( $3.5 \mathrm{t} / \mathrm{ha} / \mathrm{yr})$, and then by afforestation (post-LCDB 1) and subalpine shrubland, both with $2.9 \mathrm{t} / \mathrm{ha} / \mathrm{yr}$. Manuka and or kanuka follows next with a rate of $2.8 \mathrm{t} / \mathrm{ha} / \mathrm{yr}$, then river cover at $2.4 \mathrm{t} / \mathrm{ha} / \mathrm{yr}$. High producing exotic grassland has a mean erosion rate of 
Table 1 Areas of productive land (ha) by Land Cover Class in the Bay of Plenty by Land Use Capability Class (Guinto \& Cusi 2012).

\begin{tabular}{lccccccc}
\hline $\begin{array}{l}\text { LUC } \\
\text { Class }\end{array}$ & $\begin{array}{c}\text { High \& Low } \\
\text { Producing Ex- } \\
\text { otic Grassland }\end{array}$ & $\begin{array}{c}\text { Orchard \& Other Short-rotation } \\
\text { Propland }\end{array}$ & $\begin{array}{c}\text { Pine Forest, } \\
\text { Closed Canopy }\end{array}$ & $\begin{array}{c}\text { Pine Forest, } \\
\text { Open Canopy }\end{array}$ & $\begin{array}{c}\text { Forest, } \\
\text { Harvested }\end{array}$ & $\begin{array}{c}\text { Total Area by } \\
\text { LUC Class }\end{array}$ \\
\hline 1 & 2,316 & 139 & 254 & 1 & 0 & 0 & 2,712 \\
2 & 37,688 & 7,639 & 3,980 & 176 & 90 & 11 & 49,587 \\
3 & 49,467 & 5,615 & 1,403 & 4,930 & 2,629 & 1,157 & 65,203 \\
4 & 52,686 & 3,710 & 2,021 & 47,015 & 25,736 & 20,709 & 151,879 \\
5 & 568 & 42 & 0 & 22 & 3 & 3 & 641 \\
6 & 82,134 & 2,102 & 887 & 51,325 & 20,368 & 15,809 & 172,628 \\
7 & 22,360 & 626 & 79 & 43,670 & 11,875 & 12,892 & 91,505 \\
8 & 3,485 & 248 & 47 & 4,460 & 1,105 & 925 & 10,273 \\
Total & 250,704 & 20,121 & 8,671 & 151,599 & 61,816 & 51,506 & 544,428 \\
\hline
\end{tabular}

Note: An anomaly exists in Table 1 where transposing up to date LCDB 2 land cover over earlier mapped Land Use Capability polygons has resulted in some LUC Classes showing land use which clearly would not occur on that LUC class.

Table 2 Summary of Land Use Capability Analysis of the Bay of Plenty Region

\begin{tabular}{|c|c|c|c|}
\hline LUC Class & Area (ha) & Percentage & $\begin{array}{l}\text { Composition of dominant land cover } \\
\text { (\% of LUC Class area) }\end{array}$ \\
\hline 1 & $2,839.9$ & 0.24 & $\begin{array}{l}\text { High producing exotic grassland }(81.6 \%) \\
\text { Short rotation crops }(9.0 \%) \\
\text { Orchards and other perennial crops }(4.9 \%)\end{array}$ \\
\hline 2 & $53,198.1$ & 4.46 & $\begin{array}{l}\text { High producing exotic grassland }(70.8 \%) \\
\text { Orchards and other perennial crops }(14.4 \%) \\
\text { Short rotation crops }(7.5 \%)\end{array}$ \\
\hline 3 & $74,774.4$ & 6.27 & $\begin{array}{l}\text { High producing exotic grassland }(66.2 \%) \\
\text { Orchards and other perennial crops }(7.5 \%) \\
\text { Pine forest, closed canopy }(6.6 \%) \\
\text { Pine forest, open canopy }(3.5 \%)\end{array}$ \\
\hline 4 & $182,950.1$ & 15.33 & $\begin{array}{l}\text { High producing exotic grassland }(28.8 \%) \\
\text { Pine forest, closed canopy }(25.7 \%) \\
\text { Pine forest, open canopy }(14.1 \%) \\
\text { Forest, harvested }(11.3 \%) \\
\text { Indigenous forest }(8.1 \%)\end{array}$ \\
\hline Arable total & $313,762.5$ & $(26.30)$ & \\
\hline 5 & 659.1 & 0.06 & $\begin{array}{l}\text { High producing exotic grassland }(86.3 \%) \\
\text { Orchard and other perennial crops }(6.5 \%) \\
\text { Pine forest, closed canopy }(3.4 \%)\end{array}$ \\
\hline 6 & $283,029.5$ & 23.72 & $\begin{array}{l}\text { High producing exotic grassland }(29.0 \%) \\
\text { Indigenous forest }(28.9 \%) \\
\text { Pine forest, closed canopy }(18.1 \%) \\
\text { Pine forest, open canopy }(7.2 \%) \\
\text { Forest, harvested }(5.6 \%)\end{array}$ \\
\hline 7 & $393,059.3$ & 32.95 & $\begin{array}{l}\text { Indigenous forest }(66.7 \%) \\
\text { High producing exotic grassland }(5.7 \%) \\
\text { Broadleaved indigenous hardwoods (3.7\%) } \\
\text { Manuka/kanuka (3.5\%) } \\
\text { Forest, harvested (3.3\%) } \\
\text { Pine forest, open canopy }(3.0 \%)\end{array}$ \\
\hline 8 & $202,480.6$ & 16.97 & $\begin{array}{l}\text { Indigenous forest ( } 87.9 \%) \\
\text { Broadleaved indigenous hardwoods }(2.7 \%) \\
\text { Pine forest, closed canopy }(2.2 \%)\end{array}$ \\
\hline Non-arable, total & $879,228.5$ & (73.70) & \\
\hline Grand total & $1,192,991.0$ & 100.00 & \\
\hline
\end{tabular}


$2 \mathrm{t} / \mathrm{ha} / \mathrm{yr}$. The remaining land cover classes have mean erosion rates below $2 \mathrm{t} / \mathrm{ha} / \mathrm{yr}$. With the exception of LUC Class 7 land, all LUC classes have mean erosion rates below $2 \mathrm{t} / \mathrm{ha} / \mathrm{yr}$, (Guinto \& Cusi 2012).

Erosion is the region's hidden tempest, as when it occurs, often under intense rainfall, the results are devastating. The landscape looks relatively benign due to its rounded and rolling nature buried under various volcanic eruptions, but when it is exposed it is highly mobile under pressure from water. Our most devastating erosion type is gully erosion which occurs in our narrow valley floors. This happens often when some cropping activity or earthworks has occurred followed by heavy rain. Approximately 56000 ha is vulnerable to this erosion type. Once it has occurred it can be halted but cannot be repaired for use again like a soil slip. Surface or sheet erosion is another dominant type and this occurs mainly due to activity on the land.

\section{Farming in the Bay of Plenty}

There is only $23 \%$ of the regional area in pastoral production. Of this area $60 \%$ is sheep and beef, $32 \%$ is dairying, $3 \%$ deer, $2 \%$ arable and $3 \%$ other activities. In 2010/11 the Bay of Plenty dairy herd numbered 600, containing 192038 cows (LIC \& DairyNZ 2011) or $4.2 \%$ of cows nationally. The average herd size was 320 on an average of 117 effective hectares at 2.75 cows per hectare. This total number of dairy cows is down from 2008 where the tally was 243923 (MAF Policy 2009) and 272000 in 2005 (MAF Policy 2006). It is quite possible that the current number of dairy cows has declined again.

Beef cattle numbers were approximately 102682 in 2008 which had declined by about 6000 from 2005 . Sheep tallied 346445 in 2008, and while this was less than the 2005 tally, the number has fluctuated up and down over the years. Deer were following a similar pattern and tallied 51000 in 2008 declining from previous higher numbers, (MAF Policy 2009). Kiwifruit occupied 9,000 hectares of land concentrated around Te Puke, Tauranga and Ōpōtiki with growth and development occurring near Te Kaha.

\section{Regional demographics and economy}

The "Bay of Plenty" was a term coined by Captain Cook when his ship Endeavour rounded East Cape on 29 October1769 and came upon local populations large and prosperous (Salmond 2003). The Māori name for the Bay of Plenty is Te Moana a Toi, the sea of Toi, commemorating the legendary ancestor Toitehuatahi. Demographically the Bay of Plenty is unique with one of the largest Māori populations in the country $-30 \%$ of the total population. Three in ten Maori are fluent in $\mathrm{Te}$ Reo Māori, the second highest rate in the country. The region has a high than national percentage of residents in their retirement years ( $>65$ age group $-16 \%$ ) and a lower than national percentage of young working age residents (25-34 age group - 11\%), where the national average for both is $13 \%$. The fastest growth group is the less than 25 years old. The region is growing by around 3000 people each year, mostly in the western districts. The eastern districts are declining in population and have a $-1 \%$ growth statistic currently. Over the next 20 years the region's growth looks set to continue at the second fastest rate in the country. At the same time, there is a concern that as the overall population increases the eastern districts might be left behind (Bay of Plenty Regional Council 2011).

The region's economy, like that of the rest of the country, has been affected by the recent recession. Overall, the region's economy contributes approximately $\$ 10.5 \mathrm{~b}$ (or 5\%) of New Zealand's GDP, from a population of 300000 and a workforce of 118000 full-time equivalents, (Leung-Wai et al. 2011). The Property and Business Services sector is the largest contributor, while the combined Wood and Paper Product Manufacturing and Forestry and Logging industries - the forestry sector - was the second largest contributor in 2010 to regional GPD at approximately $\$ 1 \mathrm{~b}$. The Manufacturing sector ranks third and the Agriculture sector ranks fourth with $\$ 0.6 \mathrm{~b}$. However the biggest employer is the primary sector of agriculture, forestry and fishing at $14 \%$, (Leung-Wai et al. 2011). These sectors account for $45 \%$ of the working population in the Eastern Bay of Plenty. While there has been a rebound in job numbers and building consents, unemployment has continued to rise at a faster rate than the national average. Bay of Plenty has experienced a large increase in the median household income throughout the 2000s, ranking third nationally, but it also has the fifth highest proportion of residents living in low income conditions - that is they have an income of less than $60 \%$ of the national household income levels. One in five residents lives in low income households and low income communities, (Leung-Wai et al. 2011).

Māori currently own approximately $33 \%$ or 400000 hectares, (Bay of Plenty Regional Council 2013b). What proportion of this land is in agri-business is unknown, but approximately 235000 ha are in Pinus radiata forests, which is the majority of our regional forestry sector land at $82 \%$. Overall Māori land is estimated at having between $\$ 5.5 \mathrm{~b}$ and $\$ 8.9 \mathrm{~b}$ in assets. The Māori economy is and will be a formidable force with massive potential. We have 35 iwi and over 230 hapū and more than 160 marae located across the region (Bay of Plenty Regional Council 2009). The Treaty landscape is rich, diverse and dynamic. So far the 
region has eight comprehensive Treaty settlements with a further 17 being progressed with the Office of Treaty Settlements on behalf of the Crown. Within the next 2-5 years there will be 25 further Treaty settlements, (Bay of Plenty Regional Council 2013b). Several of the settlements involve implementation responsibility for the Bay of Plenty Regional Council, particularly around the co-governance of natural resource. To date we are responsible for two statutory co-governance forums for the Rotorua Te Arawa Lakes and Rangitāiki River and two more are on the horizon for the Kaituna River and Tauranga Harbour. The Council has also supported many of the iwi in developing iwi management plans which the Council must take into account when involved within an iwi's rohe. The evolving landscape of Māori land ownership, business growth and governance is increasing exponentially for the Council and other regional agencies which are putting pressure on resources to support all of the engagement and requirements.

\section{Regional strategic focuses}

Regionally there has been significant focus on identifying opportunities and to support sector strategies. This has been driven by the Bay of Connections Governance Group that has been in place since 2007. It has been instrumental in providing collaborative credibility and connection, ensuring industry input and providing relevance to growing the various sectors. The region's strategic focus is based on 13 focus areas of industry as shown in Figure 1.

The Bay of Plenty Regional Council has its own strategic focuses for the community under the Ten Year Plan. They are the Rotorua Lakes, Tauranga Harbour, Regional Infrastructure Fund, Water programme of action, River Scheme sustainability, Regional Pest Management Strategy and the Kaituna Maketū Strategy. These priorities are shaping the Council's business currently and link into the regions other strategies for growth and development, such as the Smart Growth Strategy in Tauranga.

Most of the aforementioned strategic foci involves the community and landowners in particular. The Bay of Plenty Regional Council, like most councils, has a Natural Resource Operations Group which implements the operational activities that are required to achieve the results the community are looking for. Two key programmes are the Sustainable Land Use and Biodiversity programmes which aim to work with landowners to reduce the impact of issues ranging from storms and heavy rainfall, erosion, and nutrient management to protecting the remaining threatened indigenous habitats we have. Both programmes are voluntary and provide grant funding or trees at cost for work completed on an annual basis. Catchment management has always been the underlying approach to the work but that has become more emphasised under new legislation and by the Land and Water Forum. Land Management Officers are allocated catchments to manage based on a catchment action plan which has analysed the physical resources of the catchment, current land cover and land use and then aligned that information with the issues of that catchment. Within Tauranga Harbour there are 17 catchments draining to the harbour which all have a plan and assigned Land Management Officer. Each year a set target of river or stream distance is required to be secured from erosion or stock access. Across the region we measure the effectiveness of our work in metres of river or streams protected and calculate the land use capability unit hectares at site which provides a measure of reduced sediment and erosivity.

\section{Water quality and the Lakes}

Water quality and the strong spiritual connection to water by tangata whenua in the region is dominated by what affects our receiving environments - our lakes, estuaries, harbours and rivers. All of our receiving environments, whether confined lake catchments or rivers draining into estuaries, are affected by nitrogen, phosphate, sediment and faecal material. Our rivers are mostly co-limited by nitrogen and phosphate so we have to manage the effects of both. Water quality monitoring reports are showing that we are still seeing an decline in water quality in nearly all of our monitored rivers in one or more of the four aforementioned key indicators. Suspended solids and turbidity are indicating a decreasing water clarity and increased sediment loading in about half of our rivers. Total nitrogen (TN), ammonium-nitrogen and oxides of nitrogen (TOx-N) are increasing, often significantly, across most of our rivers. Trends related to dissolved reactive phosphorous (DRP) and total phosphorous (TP) are variable across the region (Scholes \& McIntosh 2009). Where work has been occurring with landowners there has been improvement, such as in the Nukuhou River, a small catchment east of Whakatane. A recent overview of faecal contamination in our rivers and streams has shown that some rivers and streams have contamination levels above recreational water quality guidelines and in some cases these levels are increasing. We understand that most of the elevated levels of contamination occur during and following rainfall events which highlights the on-going need to focus on diffuse sources. This is being addressed by our current programmes and will be part of the catchment management focuses into the future.

The Rotorua Lakes dominate the region's focus and will for a time to come, so that they retain their 
iconic status as destinations, their spiritual and cultural identities and of course their water quality. Managing the lakes is now under the banner of the Rotorua Te Arawa Lakes programme which has three partners; Rotorua District Council, Te Arawa Lakes Trust and the Bay of Plenty Regional Council. Their primary focus are the four Deed Funded lakes; Rotorua, Rotoehu, Rotoiti and Ōkāreka; this is a jointly funded programme with the Ministry for the Environment. The overarching goal of the Rotorua Te Arawa Lakes programme is to reach community aspirations of water quality. This is measured annually by the Trophic Level Index.

The current Rotorua Te Arawa Lakes water quality trend is as follows;

Improving: Rotorua, Rotoiti, Rotoehu

Stable:Rotomā, Ōkataina, Ōkāreka, Tikitapu, Rerewhakaaitu Declining:Tarawera, Rotokakahi, Rotomahana

Needs further investigating: Okaro

Both rules and an incentive scheme to reach the sustainable nutrient load are in the early stages of development for the Lake Rotorua catchment. A lot of work is being done to make sure the farming community affected are involved in the process. As part of this, a Lake Rotorua Catchment Stakeholder Advisory Group has been formed to provide input, advice and recommendations on both the rules and incentives. The group includes 12-15 members from the Lake Rotorua Primary Producers Collective, Lakes Water Quality Society, Bay of Plenty Regional Council, Rotorua District Council, Te Arawa Lakes Trust, Office of the Maori Trustee, forestry sector, iwi landowners and small block owners. The Stakeholder Advisory Group meets regularly to share their views, knowledge and expertise. Other stakeholders, affected individuals and the broader Rotorua community will also be consulted.

What is the benchmarking proposition? The purpose of benchmarking is to determine the amount of nitrogen and phosphorus lost from rural properties within the surface water catchment areas of Lakes Rotorua, Rotoiti, Rotoehu. Okareka and Okaro. These nutrient levels are called the "Rule 11 benchmark". The landowner is then required to manage their land within their benchmark in order for the land use to remain as a permitted activity under Rule 11 . All properties over 0.4 ha in the catchment areas must be benchmarked. A property's allowed nutrient limit, or benchmark is set using information on how the land was used during the benchmark period of 1 July 2001 to 20 June 2004. This information is entered into Overseer $(\mathrm{C}$ - a farm nutrient budgeting model. The Overseer $(\mathrm{C}$ model predicts the annual average discharge of nitrogen and phosphorus from the property. All properties in the Rule 11 area must comply with Rule 11, even if the property has not been benchmarked. This means that current and future owners are still restricted by the nutrient loss from the land's use during the benchmark period.

What will be the incentives for Lake Rotorua alone? To reach the sustainable nitrogen load for Lake Rotorua significant land management and land use change is needed. The rules will set out the limits and the timeframe to get to the target. To help land-owners with the cost of these changes, a Land Use Incentive Fund is being developed. At the time of writing this paper, the incentives were still in development. Dependent on Crown funding, the programme may have $\$ 45.5$ million to provide incentives for innovative land use change in the Lake Rotorua catchment. However work to date includes developing high-level principles for the funding. These include:

Land-owners will not receive incentives for good management practice. The fund will only fund land use change from good practice nitrogen loads to rule allocation level.

- Decisions will be based on cost of nitrogen per kilogram.

- Only actions contributing to significant nitrogen reductions will be funded

- Reductions must be clear, quantifiable and measureable

- Funding will not pay for nutrient reductions that are cost neutral or financially positive

- Actions must achieve long-term reductions

- Co-benefits will be part of the funding decisions e.g., economic growth, innovative technologies. (Source: www.rotorualakes.co.nz/Rotorua_incentives)

\section{NPS for Freshwater}

The National Policy Statement for Freshwater was released in May 2011 and requires regional councils to establish freshwater objectives and to set water quality and quantity limits for all bodies of water. Once the limits are set, the Bay of Plenty Regional Council then needs to undertake a programme to improve water quality and quantity for freshwater bodies not meeting objectives. The Bay of Plenty Regional Council has until 2030 to implement the programme, and has adopted an implementation programme of timelimited stages which is underway. The programme is an adaptive one by design and addresses priority areas in the short term. The four priority areas currently are: prioritising waterbodies for action e.g., Tauranga Harbour and Lake Rotorua; addressing specific issues within the plans e.g. Water and Land Plan; reviewing internal systems and knowledge gaps and; addressing water allocation issues. 


\section{Biosecurity}

Biosecurity is a very serious issue for the region and the Regional Pest Management Plan sets out what the Bay of Plenty Regional Council is trying to achieve in relation to managing current pest plants and animals. We are going to achieve this by classifying the pests and completing a full cost benefit analysis. These are determined by three factors; 1 : the severity of the threat that the pest poses environmentally, socially, and economically, 2: cost of action, and 3: effectiveness of response, both locally and regionally. The pests are classified into agency pests, exclusion and eradication pests, containment pests, and restricted pests. We all have to be on our guard, as in this last year new pests to the region were found. There was an aquatic pest plant delta arrow head (Sagittaria platyphylla), and climbing gloxinia (Lophospermum erubescens), both of which are under site plan management. Another aquatic pest plant, Senegal tea (Gymnocoronis spilanthoides), was found in an ornamental pond near Lake Rotorua, and the very invasive aquatic pest plant hornwort (Ceratophyllum dimersum) was discovered at a new site in Lake Ōkāreka. Rainbow lorikeets were captured.

By far the most devastating biosecurity incursion has been the pathogenic bacterium Psuedomonas syringae pv.Actinidae $(P s a-V)$ which attacks our kiwifruit. As of June 2013, 2102 orchards nationwide have been identified with Psa-V totalling 9745 hectares. This means that $71 \%$ of New Zealand's kiwifruit hectares are on orchards identified as having Psa-V, (Bay of Plenty Regional Council 2013c.) The Bay of Plenty contains approximately $90 \%$ of these infected orchards. Kiwifruit Vine Health Incorporated has now developed a national pest management plan to prevent the spread and minimise its impact on commercial kiwifruit. This plan is critical for its success will have a major impact on a major part of our regional economy.

\section{Conclusion}

Captain Cook certainly wasn't far off the mark in naming the wide bay he found the "Bay of Plenty". Its sub-tropical climate and abundance of food are still prevalent today, but it is intriguing as to how much land has remained unchanged and is still in indigenous vegetation today - and there are good reasons for this. What was cleared has often been replanted into exotic forest. The good all-year-round rainfall supports a variety of agricultural and horticultural opportunities. But what's the future landscape and land use going to be like? With an increasing amount of pressure from subdivision, a growing population, and the environmental management required there is no perceived release of the pressures on our rural sectors and communities which could affect the progress of rural life in the Bay of Plenty.
It is also clear that the physical resources for use in the region are vulnerable when contemplating land based activities that produce nutrients that exit to water. This is because the soil is problematic - it is structurally weak and highly leachable. This vulnerability to pressure and the impact on water means that the Bay of Plenty area requires land to be managed with a heightened level of sensitivity to its water environment. Since the earliest of time, people and water have always been linked in the Bay of Plenty because of its ability to provide kai, recreation, transportation and a spiritual connection or mauri with oneself. Without a doubt, water, its use and quality will continue to be a focus into the future.

\section{References}

Bay of Plenty Regional Council. 2009. Nga Marae A Rohe - Marae in the Environment Bay of Plenty region, 2009. Bay of Plenty Regional Council, Private Bag 364, Whakatāne, New Zealand.

Bay of Plenty Regional Council. 2011. 2011 Regional Trends. Bay of Plenty Regional Council, PO Box 364, Whakatāne, New Zealand.

Bay of Plenty Regional Council. 2013a. Water allocation status report to Bay of Plenty Regional Council Operations, Monitoring and Regulation Committee Agenda, June 20, 2013.

Bay of Plenty Regional Council. 2013b. Update on Treaty Claims and Settlements in the Bay of Plenty Region report to Bay of Plenty Regional Council Full Committee, April 24, 2013.

Bay of Plenty Regional Council. 2013c. Kiwifruit Vine Health report to Bay of Plenty Regional Council Operations, Monitoring and Regulation Committee Agenda, June 20, 2013. Page 17.

Guinto, D.; Cusi, M. 2012. Analysis of land cover in the Bay of Plenty region. Bay of Plenty Regional Council Internal Report 2012/08, PO Box 364, Whakatāne, New Zealand.

Leung-Wai J, Dixon H, Sanderson K, 2011. Update of the Bay of Connections Regional Economic Development Strategy: Economic and Industry Profile of the Bay of Plenty Region. Business and Economic Research Limited, BERL House, PO Box 10277, Wellington, New Zealand.

LIC \& DairyNZ. 2011. New Zealand Dairy Statistics 2010-11. DairyNZ, Private Bag 3221, Hamilton, New Zealand.

Lynn, I.H.; Manderson, A.K.; Page, M.J.; Harmsworth, G.R.; Eyles, G.O.; Douglas, G.B.; Mackay, A.D.; Newsome, P.J.F. 2009. Land Use Capability Survey Handbook - a New Zealand handbook for the classification of land. 3rd Ed. AgResearch, Hamilton; Landcare Research, Lincoln; GNS Science, Lower Hutt, New Zealand. 
MAF Policy. 2006. North Monitoring Report, July 2006. Ministry of Agriculture and Forestry, Wellington, New Zealand.

MAF Policy. 2009. Pastoral Sector Overview, 2009. Ministry of Agriculture and Forestry, Wellington, New Zealand.
Salmond, A. 2003. The Trial of the Cannibal Dog Captain Cook in the South Seas. Penguin Books Ltd, London. Page 128.

Scholes, P.; McIntosh, J. 2009. Water Quality of Bay of Plenty Rivers 1989-2008. Bay of Plenty Regional Council Internal Report 2009/11, PO Box 364, Whakatāne, New Zealand. 